\author{
Gülşah Narlu \\ English Language Instructor \\ BA in English Language and Literature \\ Kütahya Dumlupınar University \\ Kütahya, Turkey \\ ORCID ID 0000-0002-2520-5534 \\ gulsah.dikmeci@dpu.edu.tr
}

\title{
REPRESENTATIONS OF SOURCE CULTURE AND TARGET ONE IN EFL COURSEBOOKS (ON THE BASIS OF CONTENT ANALYSIS OF "ENGLISH FILE")
}

\begin{abstract}
As an international language, English has gained more importance in international contexts to convey cultural messages. Hence, being proficient in the English language does not only require learners to be competent in the forms and functions of the language, but they also need to consider sociocultural values. In this regard, it is significant to be aware of the differences and similarities between the source culture and target cultures to build cultural awareness and have intercultural communicative competence. Being one of the most used teaching materials, coursebooks play a crucial role to develop intercultural communicative competence by introducing various cultures. Due to the importance of coursebooks in terms of representation of cultures, this study aims to examine the frequency of appearances of source culture, target culture, and international target cultures in reading texts of "English File Elementary" and "English File Pre-Intermediate" prepared by Latham-Koenig, Oxenden, Lambert, and Seligson (2019) and identify the topics through Byram's criteria (1993). Employing content analysis method and mixedmethods, the study revealed that the representation of source culture is highly neglected while the target culture is frequently represented in the reading texts. It was also concluded that concepts and activities related to social life in various cultures are the most introduced topic in the reading texts.
\end{abstract}

Keywords: intercultural communicative competence; coursebook content analisys; cultural representation; Byram's criteria for coursebook evaluation; source culture; target culture.

\section{INTRODUCTION}

As a deep and sophisticated term, culture is defined by Brown (2000) as "the ideas, customs, skills, arts and tools that characterize a given group of people in a given period of time" (p. 177). This definition can be corroborated by the statement that culture is a collective view which distinguishes the members of a particular group or a culture from another (Hofstede, 1984). According to Byram (1997), culture is an "individual's ability to communicate and interact across cultural boundaries" (p. 7). According to these definitions, it can be remarked that culture comprises values, common world views, religion, and language besides other important components. In addition to its distinguishing nature, it can be also considered as a unifying system due to the existence of common values that are both observable and hidden.

It is widely accepted that culture consisting of different elements and language enabling the members of certain cultures to communicate with each other and with the members of other cultures are inseparably in a mutual interaction by influencing each other. Brown (1994) points out, "A language is a part of a culture and a culture is a part of a language; the two are intricately interwoven so that one cannot separate the two without losing the significance of either language or culture" (p. 165).

The relationship between culture and language can be described more clearly by emphasizing culture as the core of teaching a language which is regarded as a social practice. Language proficiency and its outcome leads to building cultural awareness (Kramsch, 1993). The quotation below shows the current situation of English as the global language and displays the fact that knowing English is also crucial in being acquainted with foreign cultures.

When Mexican pilots land their airplanes in France, they and the ground controllers use English. When German physicists want to alert the international scientific community to new 
discoveries, they first publish their findings in English. When Japanese executives conduct business with Scandinavian entrepreneurs, they negotiate in English. When pop singers write their songs, they often use lyrics or phrases in English. When demonstrators want to alert the world to their problems, they display signs in English (Hasman, 2000, p.3).

Kachru (1990) states that knowing English is like owning Aladdin's lamp when compared to other languages, which opens new gates to the English speakers in business, science, and technology. It may seem sufficient to be proficient in English to open these new gates and to be an active participant in multicultural contexts by interacting with people with whom one does not share the same mother tongue. However, it should not be overlooked that sociocultural essentials are required to be incorporated into the local and international settings appropriately and adequately to have intercultural communicative competence (Alptekin, 2002). Byram (1997) defines intercultural communicative competence as "the ability to interact with people from another country and culture in a foreign language" (p. 71).

Dombi (2013) points out that foreign language teaching should not be supposed to encourage students to acquire native-like proficiency. Instead, students should be empowered with skills, attitudes, and knowledge that are highly needed in various cultural environments to function competently. Teaching cultural elements o increase intercultural awareness, tolerance, and understanding between cultures should be given as much importance as teaching linguistic features.

When the literature has been reviewed, that there are many studies related to intercultural communicative competence; however, the number of studies addressing the issue of intercultural communicative competence in a classroom context is limited since it has started to gain attention with the recent globalization of English as a lingua franca or an international language. Thus, it is reasonable to evaluate EFL coursebooks in line with cultural representation in order to contribute to the studies in the field and to show to what extent they reflect different cultural elements to increase intercultural awareness of learners.

\section{THEORETICAL BACKGROUND}

It is a striking fact that non-native speakers of English have outnumbered native speakers and nearly a quarter of the world population is English as a Second Language (ESL) or English as a Foreign Language (EFL) speakers (Crystal, 2003). It must be kept in mind that it is quite challenging to keep track of the official number of non-native speakers; however, one can assume that it has most probably increased because of the spread of English over the last 15 years. As for teaching and learning English, it should be taken into account that there is no standard variety of English employed in every context where the medium of international communication is English (Matsuda \& Friedrich, 2011). In such a communication context where English language is used differently by speakers of various cultures, English language teaching materials should contain information about various cultures to achieve intercultural communicative competence, and the position of English as an international language (Yuen, 2011). Hilliard (2014) highlights that coursebooks are required to be evaluated from an educational perspective now that they represent the culture in both implicit and explicit ways.

Tomlinson (1998) defines the coursebook as "... a textbook that provides the basic materials for a course and it serves as an important resource used by the learners during a course. It usually covers work on grammar vocabulary, pronunciation, functions and the four skills" (p .9). As inferred, coursebooks, valuable and fundamental teaching resources in a classroom context, bring substantial advantages for teachers by providing the core materials and play a significant role in conveying the cultural content, besides linguistic features, to raise students' intercultural awareness by enriching the teaching and learning process.

Böcü (2015) points out that the integration of cultural features into the coursebooks is quite essential because students who are exposed to cultural themes are equipped with intercultural communicative competence skills. Being germane to the issue, Kramsch (1993) suggests that providing information about different cultures rather than entailing solely a particular culture encourages students to make comparisons between their culture and other cultures, to explore how 
their culture differs from other cultures, and to acquire intercultural awareness and understanding. Thus, both source culture and international target cultures besides target culture are to be involved in language teaching and learning.

According to Cortazzi and Jin (1999), EFL coursebooks can be divided into three categories based on the cultural focus. Coursebooks reflecting the characteristics of a source culture are the ones that are particularly designed for a certain country at a national level to teach the learners how to introduce their culture to foreigners. Even though these coursebooks are beneficial to teach the source culture, they are insufficient as they are believed not to foster intercultural. Secondly, it is generally observed that coursebooks reflecting the characteristics of a target culture mostly present British or American culture with commercial aims. Lastly, coursebooks representing international target culture consist of a broad variety of cultures in the countries where English is adopted as a foreign language in expanding circle or a second language in outer circle.

Although there are plenty of studies examining to what extent the source, target, and international target cultures are represented in local and global EFL coursebooks, they mostly address how different EFL coursebooks represent these cultures by adopting certain evaluation checklists and criteria (Alpay, 2009; Asgari, 2011; Baleghizadeh \& Jamali Motahed, 2010; Çakir, 2010; Çelik \& Erbay, 2013; Dehbozorgi, Amalsaleh \& Kafipour, 2014; Hamiloğlu \& Mendi, 2010; Lee 2005; Liu \& Laohawiriyanon, 2013; Santosa, 2015; Tajeddin \& Teimournezhad, 2014; Toprak \& Aksoyalp, 2015; Vettorel \& Lopriore, 2013).

For example, in her study, Doro (2013) investigated to what extent the inner circle countries where English is learned as a foreign language as in Hungary and international target cultures were represented in the coursebooks "Traveller Pre-Intermediate" and "Bloggers 1" which are used for English teaching. Analyzing the places, institutions, pictures, names, and people in the coursebooks, she concluded that countries such as the UK, the USA, Canada, and Australia were more represented frequently when compared to the source and international target cultures, and students found the way of representing certain countries disturbing as it causes some prejudices and biases towards these countries.

In another study, Aliakbari (2005) examined four locally-published EFL coursebooks in Iran to determine whether they provide sufficient cultural content for students to acquire the skills for intercultural communication. The findings of the study revealed that the coursebooks did not encourage learners to develop intercultural awareness due to insufficient cultural content.

Considering the previous research on cultural representations in EFL coursebooks, it is crucial to conduct a new study presenting the source, target, and international target cultures in different proficiency levels of an EFL coursebook. For this reason, the present study seeks answers to the following research questions by analyzing the representation of the source, target and international target cultures in reading texts in the latest edition of the EFL coursebook "English File Elementary" and "English File Pre-Intermediate" published by Oxford University Publishing:

1. Is the distribution of source culture, target culture, and international target cultures in the 4th edition of the EFL coursebook "English File" balanced?

a. in "English File Elementary"?

b. in "English File Pre-Intermediate"?

2. What is the frequency of categories of Byram's (1993) criteria for coursebook evaluation in these coursebooks?

3. Do these coursebooks have a balanced distribution of countries, cities, languages, and nationalities?

\section{METHODS}

Descriptive content analysis to quantify the frequency of the appearance of the source culture, target culture, and international target cultures in the written texts of the coursebooks has been employed as the research method. Content analysis can be considered as a reliable research method 
allowing researchers to describe the target subject quantitatively and qualitatively, which enables the researchers to make valid and reliable inferences (Neuendorf, 2002).

The written texts have been selected because of the rich authentic content. Also, a broad range of research on intercultural communicative competence mainly focuses on speaking skills, and the reading skills have been comparatively neglected. Moreover, all the reading texts in the coursebooks are authentic materials extracted from the British press, websites, and blogs. When it comes to the reason why the mentioned coursebook series has been selected to carry out a study, it lies behind the fact that the 4th edition of the coursebook was first published in 2019 and the number of studies including this coursebook is considerably limited.

Moreover, the impact study carried out by Oxford University Press (2018) in collaboration with the National Foundation for Educational Research and Oxford University Department of Education shows that $71 \%$ of the participants expressed that they found the reading texts interesting. However, participants of the study are 299 teachers from 33 countries excluding teachers from Turkey although the coursebook is also used in Turkish EFL classes.

Besides the aim of determining whether there is a balance in the distribution of source culture, target culture and international target cultures in elementary and pre-intermediate levels of "English File", it is also aimed through the current study to contribute to the literature by filling the aforementioned gap which is the lack of research focusing on the $4^{\text {th }}$ edition of the coursebook and to give grounded coursebook user feedback to Oxford University Press by paving the way for the next local impact of the study which is supposed to include Turkish teachers using the coursebook.

\subsection{Sample}

This study aims to investigate the representation of source culture, target culture, and international target cultures in the 4th edition of the EFL coursebook "English File" published in 2019 by Oxford University Press. The coursebook has beginner, elementary, pre-intermediate, intermediate, intermediate plus, upper-intermediate, and advanced levels, and each level includes grammar, vocabulary, pronunciation, reading, writing, speaking, and listening sections. After the decision on the materials development unit at Kütahya Dumlupınar University, three levels of "English File", namely elementary, pre-intermediate, and intermediate levels, have been used at Kütahya Dumlupinar University for the intensive English program since the 2019-2020 academic year. The intensive English program was designed for prospective students who would study in such departments as English Language and Literature, and Mathematics which offer departmental courses in English and for those who voluntarily want to receive English education before they take the departmental courses. Following a placement test, students are assigned to beginner and elementary proficiency levels. Similarly, students studying English Language and Literature are assigned to intermediate-advanced proficiency levels where the teaching program is different from beginner and elementary levels. For this reason, the coursebook which is presented to more students in beginner and elementary levels was selected.

The aforementioned three levels of "English File" have been used for beginner and elementary level students; however, the intermediate level could not be included in the study due to the Corona pandemic which has affected formal education negatively and led the teachers to use the intermediate level of the coursebook through distance education by excluding some parts of the coursebook, which resulted in its exclusion from the study since it may not be thoroughly completed by the teachers and the students.

\subsection{Instruments}

Byram's (1993) criteria for textbook evaluation were used to analyze the cultural content which was categorized by using Cortazzi and Jin's (1999) model for the evaluation of culture in coursebooks. As discovered by Sorongan, Susanti, and Syahri (2014), Byram's (1993) criteria, consisting of 8 categories with subcategories for each one, are crucial in the fact that they include sociological factors such as class and interaction as well as historical and geographical subjects, 
which makes the criteria practical and comprehensive as most cultural aspects are represented. Also, a coding schema provided in Table 2 was prepared following Byram's (1993) criteria.

\subsection{Data collection and analysis}

To figure out whether elementary and pre-intermediate levels of the coursebook include a balanced distribution of the source culture, target culture, and international target cultures, reading texts were identified. The number of the appearances of cultural elements in Byram's criteria for source culture, target culture, and international target cultures was calculated and placed into the coding scheme.

To identify which countries, cities, languages, and nationalities appear most in the reading sections of these coursebooks, each country, city, language, and nationality in the reading texts was counted and the results for elementary and pre-intermediate levels of the coursebook were compared. Two interraters using the coursebooks in their classroom checked the created coding scheme to increase the reliability of the study. After reaching an agreement, findings were interpreted.

\section{RESULTS}

The purpose of this study is to demonstrate whether the 4th edition of the EFL coursebooks "English File Elementary" and "English File Pre-Intermediate" include a balanced distribution of the source culture, target culture, and international target cultures and to compare the distribution of the representation of these cultures in these coursebooks. Additionally, the study aimed at showing which categories of Byram's (1993) criteria were integrated most into the reading texts to have an insight into the content of these texts. Another aim is to present the distribution of the names of countries, cities, languages, and nationalities in the reading texts of the coursebooks to ensure that there is balanced distribution of these cultural elements. Hereafter, the coursebooks will be referred to as EFE for "English File Elementary" and EFPI for "English File Pre-Intermediate".

To interpret and discuss the results on a more grounded basis, first the total number of reading texts was determined. As Table 1 shows, EFPI includes more reading texts than in EFE. The reason for this difference may be the aim of preventing anxiety of less proficient learners. As learners become more proficient and their comprehension level increases, it is expected to have an expansion and extension in the reading materials. Although the number of reading texts in EFPI is higher than EFE, only one-quarter of the reading texts in EFPI includes cultural elements while it corresponds to $36 \%$ in EFE.

Table 1. The number of reading texts in EFE and EFPI

\begin{tabular}{lll}
\hline COURSEBOOKS & EFE & EFPI \\
\hline Reading Texts Representing Cultures & 29 & 23 \\
Neutral Reading Texts (not including cultural elements) & 52 & 69 \\
TOTAL & 81 & 92 \\
\hline
\end{tabular}

\subsection{Results for the first research question}

The frequency of occurrences of the cultural elements in EFE and EFPI by drawing a detailed picture to have a better understanding of findings and to answer the first research question is presented in Table 2. When the first category in Byram's (1993) criteria is examined, it is seen that EFPI does not provide any information about social class, regional identity, and ethnic minorities in the source culture, target culture, and international target cultures while EFE integrates these elements into five reading texts, in which people from Turkey, Oman, Iraq, Canada, and China mention the similarities and differences between living in the United Kingdom (the UK) and their countries. Also, the other three reading texts introduce different regions known for the long lifespan of people residing there and regional identities of people living in these regions. In another 
reading text about what the British like about the UK, it is emphasized that ethnic minorities in the UK such as Indians have contributed to British cuisine with their special spices and foods.

The second category shows how social interaction with different levels of formality, use of gestures and body language, greeting styles, and gender factors is represented in source culture, target culture, and international target cultures. As can be seen in Table 2, the most frequent element in reading texts in EFE is the formality level in social interactions in different cultures. In one of the readings, a Pakistani person who went to live in the US expresses the situations he found surprising. He states that American people call their boss, teachers, old people, and the people they do not know well by their first name, which he found rude. A Turkish man states that the Turkish work hard in Turkey, but the British do not work as much as Turkish people do. He continues by saying that British people want to go home as soon as they finish work. This comparison is one of the two appearances of the source culture in EFE. In another reading text, a French person living in Liverpool expresses her happiness as people in the street call her 'darling', 'sweetheart', and 'love', so she thinks British people are friendly. Although EFE provides some information about social interaction in different cultures, EFPI can be considered poor in this respect.

As for the other category in Byram's (1993) criteria, beliefs and behaviors in the source culture, target culture, and international target cultures. This category involves moral and religious beliefs as well as daily routines. It is seen in Table 2 that EFE includes several reading texts about daily routines in the target culture and international target cultures. Even though the number of appearances is limited in EFPI, the reading text about a couple going for a walk in botanical gardens in Paris on Saturdays to feed animals gives a small clue about one of the couple's habits. The reading texts in EFE are about the daily life of American teens, the commute to work and school by Tube in London, the daily routine of an Iranian doctor living in the UK and David Guetta who is a famous DJ living in Ibiza, and a typical week of a Spanish person.

Cultural elements in the category of social and political institutions are one of the most frequent elements throughout the coursebooks under examination. To mention the content of the reading texts in EFE, an Omani woman living in Manchester states that women in the UK have freedom and she also benefits from freedom. She adds that she had to go to the bank with her brother in Oman. In another reading text, a Belarussian woman living in the US points out that the salary of the American President is nearly the same as a doctor's and he is not the richest person, which is surprising for her. She also claims that hospitals in the US are very well-equipped. Lastly, she says that American doctors explain everything to their patients, which is not typical of Belarussian doctors. Furthermore, an Indian person finds the tipping system in hairdressers in the US surprising as she already pays for the service. Nevertheless, she feels safe in the US, especially when she uses the subway in New York City since it is not as dangerous as in India and the police officers prevent any frightening and disturbing acts in public transport. As for the EFPI, it provides information about a Spanish law that obligates? children under the age of 18 to do chores at home and help their families. In addition to these examples reflecting elements related to cultures, it is not ignorable that both levels of "English File" coursebooks introduce many companies and businesses belonging to the target culture and the international target cultures such as the Rockefeller Center, Care to Learn organization, Topshop, Primark, eBay, Ryanair, Twitter, Facebook, Instagram, H\&M, Zara, Apple, The Body Shop, Nike, Ikea, and Uniqlo. As Lazović (2017) suggests advertisements are crucial regarding sociocultural aspects in language teaching. The integration of advertisements into the teaching materials can be practical for learners as they reflect cultural connotations and values. However, she adds that only the members of the target culture can understand the references for certain advertisements. Thus, coursebook developers are expected to have a holistic and global standpoint in the integration of the names of companies, businesses, and brands to address learners from different cultures. It is yet a must to draw attention to the fact that neither level of "English File" introduces well-known international companies and businesses belonging to the source culture although various international companies and businesses are mentioned in the reading texts. Various elements included in the socialization and the life cycle category such as family, school, employment, media, ceremonies, art, food, relationship, and sport were examined in the reading 
texts, and it was found that both levels provide rich content embodying these elements. One of the reading texts presenting a daughter trying to find a girlfriend for her father living in Surrey exemplifies how family relationships are in the target culture. It is indicated in another reading text that a man from Ecuador used to work 15 hours a day and earn half of the money he earns in the US by working less, but moving to the US enabled him to pay the bills and rent, to have a social life, and to buy luxuries like Xbox. As for the other elements, "English File" promotes media, ceremonies, foods, sports, and arts peculiar to certain cultures. Some of these elements represented in both levels are the media organs such as BBC, The Guardian, Tinder, Facebook, Instagram, Twitter, Netflix, The Peter Gordon Breakfast Show, Trip Advisor, Reader's Digest, and the Daily Mail; the Open Air Theatre in Regent's Park in London, Victoria and Albert Museum, and Hollywood as outstanding places; Sherlock Holmes, curry, fish and chips, Scotch egg, Arsenal football club, Mexican wave, Italian beverages and food such as pizza, mozzarella, ravioli, espresso, and latte. It should be also noted that foods such as mantı and pastırma belonging to Turkish culture are mentioned in one of the reading texts in EFPI.

The national history category in Byram's (1993) criteria is about the historical and contemporary events considered as a part of national identity. Table 2 shows that both levels of the coursebook mostly display events from the target culture and international target cultures such as the London Marathon, Christmas, Champions League, the case of Langham Hotel which is reputed to be haunted, New Year's Eve, the Civil Rights Movement in the United States, Comic-Con, and the Oscar Ceremony. It would enrich the content of the reading texts in terms of intercultural awareness if such events as National Sovereignty and Children's Day, Ramadan, and the Eurasia Marathon reflecting the source culture had also been included in the coursebooks. According to Alptekin (1993), EFL materials should present content by providing a transition from familiar to unfamiliar since learners tend to interpret what they have learned pursuant to their existing socially acquired knowledge. Thus, it is unrealistic to expect learners to fully comprehend the cultural events and special days which they have never experienced without accommodating them to the ones in their native setting.

Moreover, the coursebooks reveal certain geographical factors describing a particular culture. Being the most dominant culture introduced throughout the coursebooks, target culture is represented with specific examples of national geography including Central Park in the US, the scenery in Cornwall and Scotland, Treetop Walkway, and Hyde Park. In addition, international target cultures are represented through their typical weather conditions and scenery such as sunny Mexico. It should be remarked here that the source culture appears in EFPI with the introduction of one of the famous mountains, Erciyes, situated in the Kayseri city of Turkey.

The final category in Byram's (1993) criteria is stereotypes and national identity, consisting of elements like famous people and bands, monuments, and folktales. Both levels of the coursebook introduce many famous people, but it is unfortunate that they all represent the target culture. Some of the most introduced famous characters in the coursebooks are: Brad Pitt, Shakespeare, Coldplay, the movie character James Bond, Agatha Christie, J. K. Rowling, Adele, Stephan King, Sir Ian McKellen, Pink, Martin Luther King, Alfred Hitchcock, Jude Law, and Matt Damon. As for famous places and monuments, EFPI introduces the city of Kayseri as to source culture; however, most of the places represented belong to the target culture. Although the coursebooks do not particularly employ reading texts including stereotypes and folktales, both levels retell stories and folktales which belong to international target cultures, but these are not included in Table 2 as the information provided in the reading texts is not clear. Finally, one of the reading texts in EFPI discusses whether British people are really poor language learners or not, which is one of the commonly held stereotypes attributed to the British (Milton \& Meara, 1998).

It is evident that the representation of the source culture is fairly limited in both EFE and EFPI, and that the coursebooks present the target culture more extensively when compared to the international target cultures and source culture. Considering the frequency of appearances of the cultural elements, it can be concluded that the distribution of cultural elements in the source culture, target culture, and international target cultures is not balanced in either of the coursebooks. 
Table 2. Frequency of appearances of the cultural elements in English File Elementary and English File PreIntermediate

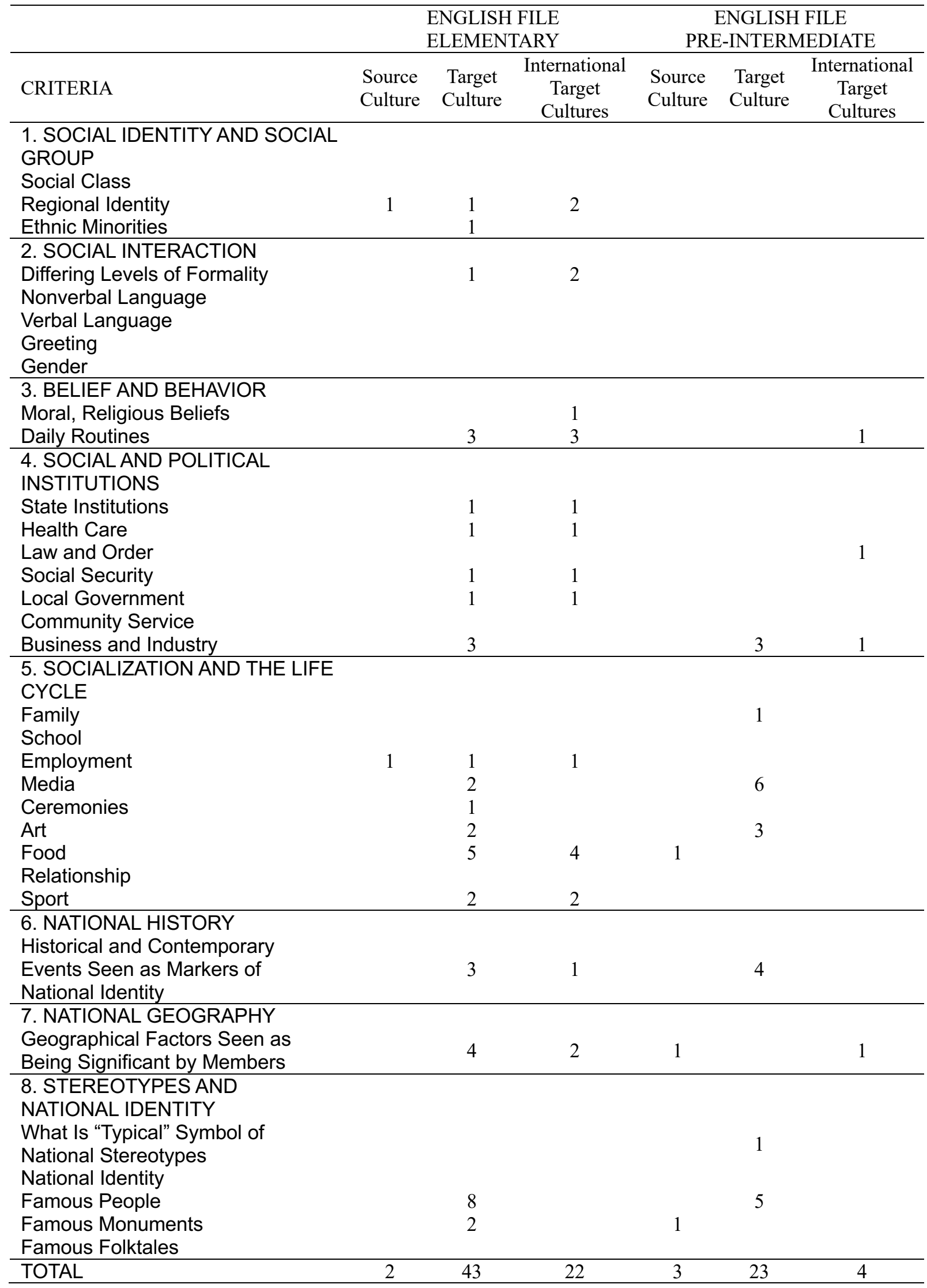

As Byram (1990) states, biased and superficial representations of reality in language teaching materials is one of the points to take into consideration. Upon reviewing and analyzing the content 
of the reading texts, it was seen that some of the reading texts in the coursebooks are culturally biased. To be clearer, it is necessary to provide some examples. In several reading texts, Omani women are represented as not having freedom, and the Turkish are introduced as hardworking people in contrast to lazy British people. Also, Pakistanis are considered respectful to their elders and strangers while Americans are deemed as rude. Lastly, the Belorussian president is not regarded as a commoner when compared to the American president who does not receive a striking amount of salary. Ndura (2004) emphasizes that teaching materials transmit societal values overtly and covertly as cultural mediators. Therefore, they have the potential of negatively or positively influencing learners' perceptions of different cultures, which requires a thorough examination of the content of materials by researchers to minimize negative and disagreeable effects caused by biased materials. It should be also kept in mind that designing books providing unbiased and engaging content for students is quite demanding and challenging; thus, piloting and much more preliminary research before releasing coursebooks are needed by the researchers.

\subsection{Results for the second research question}

Regarding the second research question, Table 3 shows the number of occurrences of categories in Byram's (1993) criteria in the reading texts in EFE and EFPI. As can be seen, the social interaction category is the least represented cultural category in EFE as in the belief and behavior category in EFPI. Moreover, the categories of social identity and social group, and social interaction are not represented in any reading texts in EFPI. Regarding the most represented categories in the reading texts, the socialization and the life cycle category is the most appearing one in both coursebooks. Also, the national geography category equally appears in both coursebooks. Consequently, EFE integrates more various topics into the reading texts than EFPI. It is suggested by Harmer (2001) that a variety of topics and genres arousing students' interest should be included in teaching materials, which gives rise to the thought that learners may lose their interest and motivation in cases in which they are exposed to EFPI after EFE because EFPI includes less various reading texts.

Table 3. Frequency of categories of Byram's (1993) criteria in EFE and EFP

\begin{tabular}{lcccc}
\hline & \multicolumn{2}{c}{$\mathbf{I}$} & \\
\hline & \multirow{2}{*}{ ERITERIA } & \multirow{2}{*}{ EFPI } & \multicolumn{2}{c}{ PERCENTAGE OF THE CATEGORIES } \\
\cline { 4 - 5 } 1. Social Identity and Social Group & 5 & 0 & $7 \%$ & EFPI \\
2. Social Interaction & 3 & 0 & $4 \%$ & $0 \%$ \\
3. Belief and Behavior & 7 & 1 & $10 \%$ & $3 \%$ \\
4. Social and Political Institutions & 11 & 5 & $16 \%$ & $17 \%$ \\
5. Socialization and the Life Cycle & 21 & 11 & $31 \%$ & $37 \%$ \\
6. National History & 4 & 4 & $6 \%$ & $13 \%$ \\
7. National Geography & 6 & 2 & $9 \%$ & $7 \%$ \\
8. Stereotypes and National Identity & 10 & 7 & $15 \%$ & $23 \%$ \\
\hline TOTAL & 67 & 30 & $100 \%$ & $100 \%$ \\
\hline
\end{tabular}

\subsection{Results for the third research question}

To answer the last research question, reading texts in both levels were examined and each appearance of countries, cities, nationalities, and languages was counted. Since certain country and nationality names such as Britain, England, America, the US, British, Brit, and English were used interchangeably in the reading texts, these were collected under a single heading, that is the UK and the US for countries, and British and American for nationalities. Besides, islands and self-governing territories were classified as the cities of the independent country they belong to. Also, no distinction was made between languages and nationalities as the main purpose of the study is to identify to what extent the source culture, target culture, and international target cultures are represented.

Table 4 shows that the UK is the most represented country, and it is proved based on the frequencies and the percentages that target culture, namely the inner and outer circle countries 
proposed by Kachru (1997), including the US, Australia, Canada, and New Zealand appear nearly at the rate of $40 \%$ in EFE. However, the rate of representation of source culture is only $3.1 \%$. When the representation of international target cultures at the rate of $58.5 \%$ is taken into account, it can be argued that EFE does not have a balanced distribution of the countries reflecting the characteristics of source culture, target culture, and international target cultures. Regarding the cities, nationalities, and languages mentioned in the reading texts in EFE, it is apparent that more than half of them belong to the target culture. As for the source culture, the city of Istanbul is included in the reading texts at $2.9 \%$, while Turkish nationality or the language is not even mentioned. The dominancy of international target cultures in countries, and target culture in cities, nationalities, and languages can be seen as evidence that they are not balancedly distributed in EFE, which leads learners to be exposed to certain cultures more.

Table 4. Countries, cities, languages, and nationalities appearing in EFE

\begin{tabular}{lcc}
\hline COUNTRY & FREQUENCY (EACH) & PERCENTAGE \\
\hline The United Kingdom & 18 & $18.8 \%$ \\
China & 6 & $6.3 \%$ \\
Spain, Australia, Canada & 5 & $5.2 \%$ \\
The USA & 4 & $4.2 \%$ \\
France, Germany, Turkey, Costa Rica, India, Morocco, New & 3 & $3.1 \%$ \\
Zealand & 2 & $2.1 \%$ \\
Italy, Mexico, Monaco, San Marino, Switzerland & & \\
Argentina, Belarus, Belgium, Chile, Dominican Republic, & 1 & $1 \%$ \\
Ecuador, Egypt, Greece, Iceland, Iran, Iraq, Japan, Nicaragua, & & \\
Oman, Pakistan, Portugal, Russia, Scotland, Sweden, & & \\
Ukraine, Venezuela, Vietnam & FREQUENCY (EACH) & PERCENTAGE \\
\hline CITY & 20 & $19 \%$ \\
\hline London & 9 & $8.6 \%$ \\
New York & 6 & $5.7 \%$ \\
Nicoya & 4 & $3.8 \%$ \\
Ikaria, Manchester, Oxford & 3 & $2.9 \%$ \\
Cambridge, Dorset, Istanbul, Sydney & 2 & $1.9 \%$ \\
Alaska, Atlanta, Budapest, Cairns, Edinburgh, Greenland, & & \\
Paris, Prague, Tokyo & & \\
Madrid, Rome, California, Liverpool, Washington D.C., & & $1 \%$ \\
Amsterdam, Caceres, Canary Islands, Cancun, Caracas, & & \\
Cardiff, Casablanca, Cornwall, Ho Chi Minh, Ibiza, & & \\
Indianapolis, Melbourne, Newcastle, Okinawa, Oviedo, & & \\
Puerto Vallarta, Punta Cana, Quito, Sardinia, Schwyz, & & $18.9 \%$ \\
Valencia, Venice, Windsor & & $5.7 \%$ \\
\hline NATIONALITY \& LANGUAGE & & $3.8 \%$ \\
\hline English/British & & $1.9 \%$ \\
American & & \\
Greek & & \\
Arabic, German, Indian, Italian, Scotch \\
Chinese, French, Irish, Mexican, Siberian, Swiss
\end{tabular}


Table 5 shows the frequency of the appearances of countries, cities, nationalities, and languages in EFPI. As can be seen, EFPI shares similarities with EFE in those countries reflecting the characteristics of international target cultures outnumber the target and the source cultures with a rate of $55.2 \%$. Turkey appears only twice in reading texts similarly to EFE. As for the cities, nationalities, and languages appearing in the reading texts in EFPI, approximately $50 \%$ of the cities belong to the target culture and the reading texts present target nationality and languages more frequently than the other cities, nationalities, and languages. Despite this high frequency, the appearance of the word Turkish and a city belonging to source culture is comparably limited. Because of the countries mostly reflecting international target cultures and cities, nationalities, and languages reflecting the target culture, EFPI does not provide a balanced distribution of the countries, cities, languages, and nationalities, as shown in Table 6.

Table 5. Countries, cities, languages, and nationalities appearing in EFPI

\begin{tabular}{lcc}
\hline COUNTRY & FREQUENCY (EACH) & PERCENTAGE \\
\hline The United Kingdom & 9 & $23.7 \%$ \\
The USA, Italy & 5 & $13.2 \%$ \\
Spain, Brazil & 4 & $10.5 \%$ \\
France, Germany, Turkey & $5.3 \%$ \\
Belgium, Sweden, Australia, Cuba, Slovakia & 2 & $2.6 \%$ \\
\hline CITY & 1 & PERCENTAGE \\
\hline Paris, Kayseri & FREQUENCY (EACH) & $10.3 \%$ \\
London & 7 & $7.4 \%$ \\
New York, Beijing, Dublin & 5 & $4.4 \%$ \\
Sydney, Madrid, Rome, Stockholm, Massachusetts, Ohio & 3 & $2.9 \%$ \\
Cambridge, Budapest, Tokyo, California, Liverpool, & 2 & $1.5 \%$ \\
Washington D.C., Bruges, Brussels, Dubrovnik, Exeter, & & \\
Frankfurt, Moscow, Surrey, Vienna, Warsaw, Torbay, Detroit, & & \\
Broadway, Devon, Rio De Janeiro, Bremen, Genoa, Sussex, & 1 & PERCENTAGE \\
San Francisco, Bratislava, Harvard, Los Angeles, Swansea & & $56.3 \%$ \\
\hline NATIONALITY \& LANGUAGE & FREQUENCY (EACH) \\
\hline English/British & 45 & $5.5 \%$ \\
American, Italian & 6 & $5 \%$ \\
French & 4 & $3.8 \%$ \\
German & 3 & $2.5 \%$ \\
Irish, African, Canadian, Spanish & 2 & $1.3 \%$ \\
Mexican, Argentinian, Japanese, Maltese, Roman, South & 1 & \\
Korean, Swedish, Turkish & & \\
\hline
\end{tabular}

When comparing the two levels of "English File" under examination in terms of the representation of countries, cities, nationalities, and languages, the low level of representation of the source culture in both coursebooks is striking. Even though countries reflecting the characteristics of international target cultures appear the most in the reading texts, the mean shows that the target culture is the most represented one followed by international target cultures. As emphasized in the previous sections, balanced coverage of different cultures helps learners enhance their intercultural comprehension, but the coursebooks examined in this study do not have a balanced representation of countries, cities, nationalities, and languages.

Table 6. Frequency of countries, cities, languages, and nationalities appearing in EFE and EFPI

\begin{tabular}{llll|lll}
\hline & \multicolumn{3}{c|}{ EFE } & \multicolumn{3}{c}{ EFPI } \\
\hline \multirow{2}{*}{ COUNTRY } & SC & TC & ITC & SC & TC & ITC \\
\cline { 2 - 7 } CITY & $3.1 \%$ & $37.5 \%$ & $58.5 \%$ & $5.3 \%$ & $39.5 \%$ & $55.2 \%$ \\
NATIONALITY \& LANGUAGE & - & $64.2 \%$ & $36.1 \%$ & $1.3 \%$ & $63.8 \%$ & $35.4 \%$ \\
\hline MEAN & $2 \%$ & $54 \%$ & $44.2 \%$ & $5.6 \%$ & $50.2 \%$ & $44.5 \%$ \\
\hline *SC, TC, and ITC stand for source culture, target culture, and international target cultures.
\end{tabular}




\section{DISCUSSION}

The globalization of the English language and its use for international communication have influenced teaching materials and coursebook, which has led designers to pay attention to the cultural elements both for instructional purposes and commercial aims. Examining mainly the inclusion of source culture, target culture, and international target cultures in EFL coursebooks, this study has focused on the content of reading texts presented in the coursebooks "English File Elementary" and "English File Pre-Intermediate". Since the 4th edition of "English File" has been recently released, the limited number of studies related to the coursebook can pave the way for further studies like the present one.

The study shows the audience what cultures are represented in these coursebooks, what topics are primarily employed in the reading texts, and what countries, cities, nationalities, and languages mostly appear in these reading texts through a comprehensive content analysis. The findings reveal that only $30 \%$ of a total of 173 reading texts in both coursebooks represents cultural elements and characteristics according to Byram's (1993) criteria.

\section{CONCLUSIONS AND SCOPE FOR FURTHER RESEARCH}

It can be concluded that the coursebooks introduce a variety of cultures, especially the target and international cultures, in reading texts by putting emphasis on social and national identities, social groups, social interaction, beliefs, behaviors, social and political institutions, social life, and stereotypes in addition to national history and geography of these cultures. Interestingly, the coursebooks do not include any well-known persons, companies, businesses, brands, special days, and events belonging to the source culture while the ones from the target and international target cultures are overly represented. It should also be noted that stereotypes or biased connotations are presented in some of the reading texts although the number of these texts is not high. Also, the most frequent topics are related to social life in the above-mentioned cultures. Finally, it was found that the countries, cities, nationalities, and languages mentioned in the coursebooks reflect the characteristics of the target culture while the source culture is noticeably overshadowed by the overt representation of the target culture.

One of the pedagogical and instructional aims of the study is to give feedback to Oxford University Press by proposing certain amendments for the next editions of the "English File". To empower learners with intercultural communicative competence, it is necessary to introduce different cultures and encourage the learners to compare the similarities and differences between the source culture and the other cultures to have a better understanding of intercultural communication.

Another major implication is that Byram's criteria can be improved and redesigned considering technological developments and new perspectives in language teaching and learning process to have a more reliable instrument for further studies since there are some overlapping categories in his criteria. Another methodological implication would be to evaluate the other five coursebooks in the series to determine the strengths and weaknesses they have in terms of cultural content. It is also suggested to examine the cultural content of the recordings and videos in the coursebooks to determine any discrepancy and parallelism between the listening and reading materials.

To sum up, this study may pave the way for further studies and draw more attention to the improvement of intercultural communicative competence in classroom settings through teaching materials.

\section{REFERENCES}

Aliakbari, M. (2005). The place of culture in Iranian ELT textbooks at the high school level. Pan Pacific Association of Applied Linguistics (PAAL), 9(1), 163-179. Retrieved from https://www.researchgate.net/publication/228688271_The_Place_of_Culture_in_Iranian_ELT_Textbooks_at_t he High_School_Level

Alpay, E. (2009). The effect of using cultural content for the development of language skills (Master's thesis, Trakya University, Edirne, Turkey). Retrieved from https://tez.yok.gov.tr/UlusalTezMerkezi/tezSorguSonucYeni.jsp 
Alptekin, C. (1993). Target-language culture in EFL materials. ELT Journal, 47(2), 136-143. http://doi.org/10.1093/elt/47.2.136

Alptekin, C. (2002). Towards intercultural communicative competence in ELT. ELT Journal, 56(1), 57-64. http://doi.org/10.1093/elt/56.1.57

Asgari, A. (2011). The compatibility of cultural value in Iranian EFL textbooks. Journal of Language Teaching and Research, 2(4), 887-894.http://doi.org/10.4304/jttr.2.4.887-894

Baleghizadeh, S., \& Jamali Motahed, M. (2010). An analysis of the ideological content of internationally-developed British and American ELT textbooks. Journal of Teaching Language Skills (JTLS), 2(2), 1-27. http://doi.org/10.22099/JTLS.2012.406

Böcü, A. B. (2015). Evaluation of textbook series 'Life' in terms of cultural components (Master's thesis, Çanakkale Onsekiz Mart University, Çanakkale, Turkey). Retrieved from http://acikerisim.lib.comu.edu.tr:8080/xmlui/handle/COMU/1236

Brown, H. D. (1994). Teaching by principles: An interactive approach to language pedagogy. New Jersey: Prentice Hall Regents.

Brown, H. D. (2000). Principles and language learning and teaching. White Addison Wesley Longman.

Byram, M. (1990). Foreign language teaching and young people's perceptions of other cultures. In B. Harrison (Ed.), Culture and the language classroom (pp. 76-87). Modern English Publications and the British Council.

Byram, M. (1993). Language and culture learning: The need for integration. In M. Byram (Ed.), Germany, its representation in textbooks for teaching German in Great Britain (pp. 3-16). Frankfurt am Main: Diesterweg.

Byram, M. (1997). Teaching and assessing intercultural communicative competence. Multilingual Matters.

Cortazzi, M., \& Jin, L. (1999). Cultural mirrors: Material and methods in the EFL classroom. In E. Hinkel (Ed.), Culture in second language teaching and learning (pp.196-219). Cambridge University Press.

Crystal, D. (2003). English as a global language. Cambridge University Press.

Çakır, İ. (2010). The frequency of culture-specific elements in the ELT coursebooks at elementary schools in Turkey. Novitas-ROYAL, 4(2), 182-189. Retrieved from https://files.eric.ed.gov/fulltext/ED552914.pdf

Çelik, S., \& Şakire, E. (2013). Cultural perspectives of Turkish ELT coursebooks: Do standardized teaching texts incorporate intercultural features? Education and Science, 38(167), 336-351. Retrieved from http://egitimvebilim.ted.org.tr/index.php/EB/article/download/1873/487

Dehbozorgi, M., Ehya, A., \& Reza, K. (2014). Exploring cultural content of three prominent EFL textbooks in Iran (A case study of American English Files, Top Notch and Four Corners). Acta Didactica Napocensia, 7(1), 69-81. Retrieved from https://files.eric.ed.gov/fulltext/EJ1053253.pdf

Dombi, J. (2013). A mixed-method study on English majors' intercultural communicative competence (Doctoral dissertation, University of Pecs, Pecs, Hungary). Retrieved from https://pea.lib.pte.hu/bitstream/handle/pea/242/dombi-judit-phd-2013.pdf?seq

Doro, K. (2013). On the move: Target vs. source culture representation in two EFL course books. In A. Witalisz (Ed.), Papers on language, culture and literature 4: Prace naukowo-dydaktyczne PWSZ w krośnie 61 (pp. 281-291). Krosno: PWSZ.

Hamiloğlu, K., \& Mendi, B. (2010). A content analysis related to the cross-cultural/intercultural elements used in EFL coursebooks. Sino-US English Teaching, 7(1), 16-24.

Harmer, J. (2001). The practice of English language teaching. Longman.

Hasman, M. A. (2000). The role of English in the 21st century. English Teaching Forum, 38(1), 2-5.

Hilliard, A. D. (2014). A critical examination of representation and culture in four English language textbooks. Language Education in Asia, 5(2), 238-252. http://doi.org/10.5746/LEiA/14/V5/I2/A06/Hilliard

Hofstede, G. (1984). Culture's consequences: International differences in work-related values. Beverly Hills, CA: Sage Publications.

Kachru, B. B. (1990). The alchemy of English: The spread, functions, and models of non-native Englishes. Urbana, IL: University of Illinois Press.

Kachru, B. B. (1997). World Englishes and English-using communities. Annual Review of Applied Linguistics, 17, $66-$ 87. https://doi.org/10.1017/S0267190500003287

Kramsch, C. (1993). Context and culture in language teaching. Oxford University Press.

Latham-Koenig, C., Oxenden, C., Lambert, J., \& Seligson, P. (2019). English file elementary student's book. Oxford University Press.

Latham-Koenig, C., Oxenden, C., Lambert, J., \& Seligson, P. (2019). English file pre-intermediate student's book. Oxford: Oxford University Press.

Lazović, V. (2017). Advertisements as authentic materials in business English class. Colloquium: New Philologies, 2(1), 71-86. https://doi.org/10.23963/cnp.2017.2.1.6

Lee, H. H. C. (2005). Intercultural teaching and learning in EFL with specific reference to the senior high school in Taiwan (Doctoral dissertation, University of Leicester, Leicester, The United Kingdom). Retrieved from https://leicester.figshare.com/articles/Intercultural_teaching_and_learning_in_EFL_with_specific_reference_to the_senior_high_school_in_Taiwan/10168268

Liu, S., \& Chonlada, L. (2013). Cultural content in EFL listening and speaking textbooks for Chinese university students. International Journal of English Language Education, 1(1), 82-93. http://dx.doi.org/10.5296/ijele.v1i1.2850 
Matsuda, A., \& Friedrich, P. (2011). English as an international language: A curriculum blueprint. World Englishes, 30(3), 332-344. https://doi.org/10.1111/j.1467-971X.2011.01717.x

Milton, J., \& Meara, P. (1998). Are the British really bad at learning foreign languages? Language Learning Journal, 18, 68-76. https://doi.org/10.1080/09571739885200291

Ndura, E. (2004). ESL and cultural bias: An analysis of elementary through high school textbooks in the Western United States of America. Language, Culture and Curriculum, 17(2), $143-153$. https://doi.org/10.1080/07908310408666689

Neuendorf, K. A. (2002). The content analysis guidebook. Thousand Oaks, CA: Sage.

Oxford University Press. (2018). Impact study. Retrieved from https://elt.oup.com/catalogue/items/global/adult_courses/english_file_fourth_edition/?cc=global\&selLanguage $=$ en\&mode $=$ hub

Santosa, I. (2015). Cultural representation in the English textbook for junior high school. Eduscience, 1(1), $25-32$. Retrieved from https://ejurnal.esaunggul.ac.id/index.php/EDU/article/view/1181

Sorongan, D. A., Susanti, R., \& Syahri, I. (2014). An analysis of local and target culture integration in English textbooks. Jurnal Bahasa \& Sastra, 15(1), 29-34. https://doi.org/10.15640/jehd.v5n2a11

Tajeddin, Z., \& Bahrebar, S. (2017). Sociological and aesthetic senses of culture represented in global and localized ELT textbooks. Journal of Teaching Language Skills (JTLS), 36(3), 119-143. https://doi.org/10.22099/JTLS.2017.25995.2299

Tajeddin, Z., \& Teimournezhad, S. (2014). Exploring the hidden agenda in the representation of culture in international and localized ELT textbooks. The Language Learning Journal, 43(2), 180-193. https://doi.org/10.1080/09571736.2013.869942

Tomlinson, B. (1998). Glossary of basic terms for materials development in language teaching and introduction. In B. Tomlinson (Ed.), Materials development in language teaching (pp. 1-24). Cambridge: Cambridge University Press.

Toprak, T. E., \& Yasemin, A. (2015). The question of re-presentation in EFL course books: Are learners of English taught about New Zealand? International Journal of Society, Culture \& Language, 3(1), 91-104. Retrieved from http://www.ijscl.net/article_9933_3.html

Vettorel, P., \& Lucilla, L. (2013). Is there ELF in ELT coursebooks? SSLLT, 3(4), 483-504.

Yuen, K. (2011). The representation of foreign cultures in English textbooks. ELT Forum, 65(4), 458-466. https://doi.org/10.14746/ssllt.2013.3.4.3

Гюльшах Нарлу. Репрезентація рідної (турецької) та іноземної культури в підручниках 3 англійської мови (на основі контент-аналізу підручників “English File"). Як міжнародна мова, англійська мова набуває все більшого значення в міжнародному контексті для передачі культурних повідомлень. Зазначено, що оволодіння англійською мовою вимагає від студентів не лише компетентності у формах та функціональному призначенні мови, але їм також потрібно враховувати соціокультурні цінності. У зв'язку з цим важливо усвідомлювати відмінності та подібності між вихідною культурою та цільовими культурами для розвитку культурної свідомості та формування міжкультурної комунікативної компетентності. Наголошено, що навчальні посібники відіграють вирішальну роль у розвитку міжкультурної комунікативної компетентності шляхом репрезентації різних культур. Через важливість навчальних посібників 3 точки зору представлення культур, це дослідження має на меті вивчити частоту появи джерельної культури, цільової культури та міжнародних цільових культур у читанні текстів в підручниках “English File Elementary" та "English File Pre-Intermediate" та визначає теми за критеріями Байрама (1993). Використовуючи метод контент-аналізу, дослідження засвідчило, що репрезентація рідної культури вкрай нехтується, тоді як цільова (іноземна) культура часто представлена в текстах для читання. Також було зроблено висновок, що поняття та діяльність, пов'язані із соціальним життям у різних культурах, є найбільш поширеною темою в текстахдля читання.

Ключові слова: міжкультурна комунікативна компетентність; контент-аналіз підручника; репрезентація культури; критерії Байрама для оцінки підручників; іноземна культура; рідна культура. 